\title{
Evaluating the Efficacy of Olive, Apple and Grape Seed Extracts in Reducing Escherichia coli O157:H7 Contamination on Organic Leafy Greens during the Wash Process
}

Buddhini P. $\mathrm{K}^{1}$, Jones $\mathrm{J}^{2}$, Ravishankar $\mathrm{S}^{3}$, Jaroni $\mathrm{D}^{1 *}$

${ }^{1}$ Robert M. Kerr Food and Agricultural Products Center and Department of Animal Science, Oklahoma State University, Stillwater, Oklahoma 74078, USA.

${ }^{2}$ Southern University Agricultural Research and Extension Center, Baton Rouge, Louisiana 70813, USA.

${ }^{3}$ School of Animal and Comparative Biomedical Sciences, University of Arizona, Tucson, Arizona 85721, USA.

\begin{abstract}
Powdered extracts of apple, olive, and grape seed were evaluated for antimicrobial activity against Escherichia coli O157:H7 during processing and subsequent short-term storage of organic leafy greens. The leafy greens tested were, baby spinach, mature bunched spinach, romaine lettuce, and iceberg lettuce. The organic leafy greens were thoroughly washed and inoculated with a three-strain cocktail of E. coli $\mathrm{O} 157: \mathrm{H} 7\left(6 \mathrm{log} \mathrm{CFU} \mathrm{ml}{ }^{-1}\right)$. Antimicrobial treatments of the extracts, prepared in phosphate buffered saline, at 1,3 , and $5 \%$ concentrations were used to wash contaminated leafy greens which were then stored for 3 days at $4^{\circ} \mathrm{C}$. Surviving E. coli O157:H7 populations were enumerated on days 0,1 , and 3 of storage. Significant reductions $(\mathrm{P}<0.05)$ in pathogen populations were observed in all the leafy greens following treatment with the plant extracts. Between 2.9-5.3 log $\mathrm{CFUg}^{-1}$ reductions in E. coli $\mathrm{O} 157: \mathrm{H} 7$ population were observed with all three concentrations $(1 \%, 3 \%$ and $5 \%)$ of olive extract by day 3 , for all the leafy greens. The $5 \%$ olive extract treatment reduced the pathogen to undetectable levels by day 0 for romaine lettuce and by day 1 for iceberg lettuce and baby spinach. Apple extract at $5 \%$ concentration showed reductions of 3.4 and $3.9 \log _{\mathrm{CFUg}}{ }^{-1}$ in iceberg and romaine lettuce, respectively. The $5 \%$ grape seed extract reduced E. coli $\mathrm{O} 157: \mathrm{H} 7$ populations by $4.4 \operatorname{logsCFUg}^{-1}$ in romaine lettuce. This study demonstrates the potential of olive, apple and grape seed extracts as antimicrobial wash treatments against E. coli O157:H7 during the processing of organic leafy greens.
\end{abstract}

Keywords: Escherichia coli O157:H7, Inhibition, Organic Leafy Greens, Plant Extracts, Antimicrobials

\section{*Corresponding Author:}

Divya Jaroni,

112 FAPC,

Department of Animal Science,

Oklahoma State University,

Stillwater, Oklahoma 74078, USA.

Tel: +01-405-744-9263

Fax: +01-405-744-4716

E-mail: divya.jaroni@okstate.edu

Recieved: September 25, 2014

Accepted: October 23, 2014

Published: November 04, 2014

Citation: Buddhini P. K, Jones J, Ravishankar S, Jaroni D (2014). Evaluating the Efficacy of Olive, Apple and Grape Seed Extracts in Reducing Escherichia coli O157:H7 Contamination on Organic Leafy Greens during the Wash Process. Int J Food Sci Nutr Diet. 03(10), 164-170. doi: http:// dx.doi.org/10.19070/2326-3350-1400031

Copyright: Jaroni $\mathbf{D}^{\odot}$ 2014. This is an open-access article distributed under the terms of the Creative Commons Attribution License, which permits unrestricted use, distribution and reproduction in any medium, provided the original author and source are credited.

\section{Introduction}

The past two decades have seen an increase in the amount of fresh produce being consumed in the United States (US). An increase in income, technological improvements, domestic production, healthier lifestyles, and the availability of a wider variety of produce are some of the factors that have attributed to this trend [31]. Likewise, there has been an increase in the consumption of organic fresh produce [9]. However, foodborne outbreaks originating from minimally processed fresh produce have also seen a parallel increase in the US, with lettuce and sprouts listed as a common source [42]. Fresh produce has also proved to be an important commodity in foodborne outbreaks outside the US, such as the Escherichia coli O104:H4 outbreak in Germany in 2011 [4], traced back to contaminated sprouts. In recent years, foodborne outbreaks associated with organic fresh produce commodities have also been reported [5-7]. Shiga-toxin producing E. coli has also been implicated in such outbreaks, including the multistate outbreak of E. coli O157:H7 infections linked to organic spinach and spring-mix blend in 2012 [7].

It has been well established that fresh produce can contain significant levels of pathogen contamination after harvest, ranging anywhere from 1 to $3 \log \mathrm{CFUg}^{-1}[1,2,8-10,15,17,27]$. These levels may be influenced by seasonal and environmental conditions, temperature, as well as the type of produce [1,17-18]. Organic produce has also been speculated to have high levels of pathogen contamination due to limited number of effective control strategies that are in place against microbial contamination, both prior to and at processing [26]. Organic growers must follow guidelines set by the United States Department of Agriculture-National Organic Program (USDA-NOP) in order to maintain an organic certification [41]. These include: composted manure or vegetable waste as fertilizers instead of synthetic fertilizers; naturally derived 
pesticides; and hydrogen peroxide, peroxyacetic acid or treated water instead of chlorine to wash produce during post-processing $[30,41]$. However, the use of animal manure-based fertilizers for organic fruit, vegetable and leafy greens has resulted in concerns about an increased risk of enteric pathogens entering the food chain [22,39-40]. Islam et al. [16] found that while composting is effective at eliminating pathogen contamination, if the manure compost contains E. coli O157:H7, the pathogen can still remain viable in the amended soil for greater than 5 months, allowing for easy contamination of the leafy greens. This highlights the need for effective antimicrobials as industrial washes to remove pathogen contamination in organically-grown salad greens, prior to packaging and before the final product reaches the consumer.

Chlorine (at $50 \mathrm{ppm}$ ) is a common and widely used sanitizer in the conventionally-grown fresh produce industry. However, in the organic fresh produce industry, the USDA-NOP prohibits the use of synthetic pesticides, fertilizers, or sanitizers and allows chlorine only at a concentration of $4 \mathrm{ppm}$ [30]. Some of the alternative wash water treatments to wash organic fresh produce include hydrogen peroxide, acetic acid, ozone, and peroxyacetic acid, of which hydrogen peroxide is the most commonly used. The antimicrobial properties of hydrogen peroxide make it a desirable sanitizer for use in the food industry. However, studies have shown that effectiveness of hydrogen peroxide is limited to specific produce and pathogen types $[2,29,38]$. In a study by Taormina and Beuchat [38], use of hydrogen peroxide spray on alfalfa seeds and sprouts did not control the growth of E. coli O157:H7. Less than $1 \log \mathrm{CFUg}^{-1}$ reduction in Salmonella population was observed on cantaloupe after treatment with $2 \%$ hydrogen peroxide, in a study by Beuchat and Ryu [2]. Treatment with hydrogen peroxide has also shown to induce extensive browning in certain types of produce like lettuce and mushrooms, unless an anti-browning agent is applied in combination [27], and therefore may not be suitable for certain kinds of produce.

In an attempt to discover new antimicrobials for washing fresh produce, the efficacy of plant extracts has previously been studied [13-14,19,25,28]. Combinations of malic acid, lactic acid, and grape seed extracts against Salmonella Typhimurium indicated a 2.6 to $3.3 \log \mathrm{CFUg}^{-1}$ reduction on spinach [14]. On the other hand, 2.1 to $4.0 \log \mathrm{CFUg}^{-1}$ reductions on spinach and 1.1 to $2.5 \log$ $\mathrm{CFUg}^{-1}$ reductions on lettuce were seen for E. coli O157:H7 [13]. Oregano (leaves) and lime (pulp) extracts showed antimicrobial properties against Salmonella spp., Shigella, and E. coli O157:H7 on cilantro, parsley, and spinach [28]. Clove extract was shown to be highly effective against $S$. Typhimurium, E. coli O157:H7, and $L$ monocytogenes on fresh lettuce [19]. However, most of these studies have focused on conventionally-grown fresh produce with very few studies evaluating the effectiveness of plant-derived antimicrobials on organically-grown leafy greens.

The focus of the present study was to test the effectiveness of selected plant extracts for washing organic leafy greens. The antimicrobial efficacy of various concentrations of apple, grape seed, and olive extracts against E. coli $\mathrm{O} 157: \mathrm{H} 7$ was evaluated under simulated washing process for organic leafy greens and storage before retail display. A three day refrigeration period was chosen for this study in an attempt to simulate storage conditions in the timeframe between postharvest processing and distribution for retail of organic leafy greens.

\section{Materials and Methods}

\section{Bacterial culture preparation and media}

A cocktail of three E. coli $\mathrm{O} 157: \mathrm{H} 7$ strains was used in this study: ATCC 43888, ATCC 43895, and ATCC 35150. Cryo-preserved cells were activated by obtaining a swab from the frozen stock culture, transferring to tryptic soy broth (TSB; Bacto ${ }^{\mathrm{TM}}$, BD, Sparks, MD) and incubating at $37^{\circ} \mathrm{C}$ for $18-24$ hrs. From the resulting culture, $100 \mu \mathrm{l}$ was then subcultured twice into TSB and maintained at $4^{\circ} \mathrm{C}$ on tryptic soy agar (TSA; Acumedia, Lansing, MI). A single colony was then picked, inoculated in $9 \mathrm{ml} \mathrm{TSB}$, and incubated at $37^{\circ} \mathrm{C}$ for $18-20 \mathrm{hrs}$ to obtain an overnight culture. This fresh overnight culture was used to prepare a cocktail by mixing equal volumes of overnight cultures for each strain. The cocktail was further diluted in buffered peptone water (BPW; Oxoid Ltd., Basingstoke, Hampshire, England) to obtain a population of $6 \operatorname{logs}$ CFU ml ${ }^{-1}$ to prepare the dip inoculum for leafy greens.

\section{Antimicrobial treatment preparation}

The extracts included in this study were obtained from apple peel (Apple Poly, L.L.C., Morril, NE), olive (CreAgri Inc., Hayward, CA), and grape seed (local natural foods store). The powdered extracts were weighed appropriately and added to sterile phosphate buffered saline (PBS: sodium chloride, Fischer Scientific, NJ, U.S.A; potassium chloride, sodium phosphate monobasic and sodium phosphate dibasic, Sigma-Aldrich, MO, U.S.A) to make $1 \%$, $3 \%$, and $5 \%$ concentrations (wt/v) for each extract. All powdered extracts were mixed thoroughly in PBS, using a stirring plate, until completely dissolved. The $\mathrm{pH}$ of the extract concentrations was measured before each experiment (Table 5).

\section{Leafy greens preparation}

The organic leafy greens tested were, romaine and iceberg lettuce, and mature and baby spinach, obtained from local stores in Stillwater, OK. The leafy greens were bought on the day of the experiment, transported on ice-packs in a cooler, and stored under refrigerated conditions $\left(4^{\circ} \mathrm{C}\right)$ until use. All the leafy greens were washed thoroughly for 2 minutes under running tap water (room temperature $\left.(\mathrm{RT}) ; 23-25^{\circ} \mathrm{C}\right)$ to remove dirt and organic particles.

Lettuce (romaine and iceberg) were prepared by discarding the outer leaves and removing the core (for iceberg lettuce only). Using aseptic techniques, the lettuce leaves were cut with sterile scissors into 1.5 x 1.5" pieces. Whole leaves of baby spinach (approximately 1.5 to 2.0 " leaves) were used whereas bunched mature spinach samples were prepared by separating individual leaves, trimming off the stalks, and then cutting the leaves into $1.5 \times 1.5$ " pieces with sterile scissors, using aseptic techniques.

\section{Antimicrobial activity of olive, grape seed, and apple ex- tracts against Escherichia coli $0157: \mathrm{H} 7$ on organic leafy greens}

Approximately $300 \mathrm{~g}$ of leafy greens were prepared as described above, weighed, placed in a sterile plastic tub (L21.4" x W17.1" $\mathrm{x}$ H5.1") and washed three times in sterile distilled water (RT, 23-25 ${ }^{\circ} \mathrm{C}$ ), using a gentle back-and-forth motion. Each washing step was carried out for 2 minutes. The leafy green samples were then exposed to UV (254 nm) light under a bio-safety cabinet for $30 \mathrm{~min}$ utes (15 minutes on each side of the leaf) to reduce background microflora. After UV exposure, a $20 \mathrm{~g}$ sample was set aside to be 
used as the negative (uninoculated) control. The remaining greens $(280 \mathrm{~g})$ were then dip inoculated [21] for 2 minutes in $2800 \mathrm{ml}$ inoculum containing the E. coli O157:H7 cocktail, prepared as described above. Inoculated leaves were then removed from the inoculum using sterile forceps and placed for 30 minutes under the bio-safety cabinet to facilitate attachment. A $20 \mathrm{~g}$ sample of inoculated leafy greens was set aside to be used as the positive control, while the remaining greens were separated into $20 \mathrm{~g}$ samples. Each of these $20 \mathrm{~g}$ samples were washed in the appropriate antimicrobial treatment solution $(200 \mathrm{ml} \mathrm{each})$ for 2 minutes with gentle agitation using a horizontal, back-and-forth motion. Along with the positive and negative experiment controls, $3 \%$ hydrogen peroxide and sterile distilled water were used as industrial controls. Phosphate buffered saline was also used as a control as it was used in the study to dissolve the powdered extracts during preparation of the antimicrobial treatments. Following the wash, leaves were removed from the liquid treatment and any excess liquid shaken off the treated leaves before placing into a sterile Whirl-Pak $^{\text {TM }}$ bag (NASCO, Fort Atkinson, WI). Treated leaves were then stored at $4^{\circ} \mathrm{C}$ for three days. On days 0 , 1 , and 3 , a $5 \mathrm{~g}$ sample from each stored sample was evaluated for surviving $E$. coli O157:H7 populations by transferring into sterile Whirl-Pak ${ }^{\text {TM }}$ bags and stomaching with $45 \mathrm{ml}$ of sterile buffered peptone water (BPW; BBL ${ }^{\mathrm{TM}}$, Difco, BD) at $230 \mathrm{rpm}$ for 1 minute. The resulting sample was then serially diluted in BPW and plated on Sorbitol MacConkey agar (SMAC; Remel Inc., Lenexa, KS) to recover surviving E. coli $\mathrm{O} 157: \mathrm{H} 7$ populations and also on tryptic soy agar (TSA, BactoTM, Becton Dickinson, Sparks, MD) to recover injured pathogen populations. Colonies of E. coli $\mathrm{O} 157: \mathrm{H} 7$ (CFU $\left.\mathrm{g}^{-1}\right)$ were counted after $18-24 \mathrm{hrs}$ of incubation at $37^{\circ} \mathrm{C}$.

\section{Statistical analysis}

Each trial, including all the controls and extract concentrations, was conducted three times. The E. coli $\mathrm{O} 157: \mathrm{H} 7$ populations (in $\left.\mathrm{CFUg}^{-1}\right)$ recovered after the antimicrobial treatments at each sampling period were converted to $\log \mathrm{CFUg}^{-1}$ and an average of the results per treatment was obtained. The limit of detection was $1 \log \mathrm{CFUg}^{-1}$. The experimental design was a $4 \times 13 \times 3$ factorial in a completely randomized design comparing: 4 leafy greens (baby spinach, mature spinach, romaine and iceberg lettuce); 13 treatments (positive control, hydrogen peroxide, PBS, water, olive extract at $1 \%, 3 \%$, and $5 \%$, apple extract at $1 \%, 3 \%$, and $5 \%$, and grape seed extract at $1 \%, 3 \%$, and $5 \%$ ) and 3 storage times $(0,1$, and 3 days). Results were analyzed using PROC MIXED in SAS v. 9.3 software (SAS Inst., Cary, NC, U.S.A) to determine the analysis of variance (ANOVA) with the significant difference between results estimated at $\mathrm{P}<0.05$.

\section{Results and Discussion}

The Results of the study, for each leafy green treated with the extracts, along with the controls, are shown in Tables 1-4. These results only show population data for E. coli O157:H7 recovered on SMAC agar since no differences were observed when compared to populations recovered on TSA (data not shown). Population data for the negative control is not shown since E. coli O157:H7 colonies were not recovered for any of the negative control trials conducted.

The results from this study (Tables 1-4) indicate that in most of the leafy greens tested, olive, grape seed, and apple extracts were able to significantly reduce E. coli $\mathrm{O} 157: \mathrm{H} 7$ populations by day 3 in comparison to the hydrogen peroxide, sterile water and PBS controls $(\mathrm{P}<0.05)$. The efficacy of all three extracts varied, depending on the produce type. In comparison to the other three leafy greens (mature spinach, romaine and iceberg lettuce), E. coli

Table 1. Antimicrobial effects of olive, apple, and grape seed extracts at 1, 3, and 5\% concentrations against Escherichia coli O157:H7 on baby spinach at $4{ }^{\circ} \mathrm{C}$

\begin{tabular}{|c|c|c|c|c|c|c|c|}
\hline \multirow[b]{2}{*}{ Treatment } & \multirow[b]{2}{*}{ Concentration $(\%)$} & \multicolumn{3}{|c|}{$\begin{array}{c}\text { Surviving E. coli O157:H7 Population } \\
\left(\log _{10} \mathrm{CFU} / \mathrm{g}\right)\end{array}$} & \multicolumn{3}{|c|}{ Log Reductions $\left(\log _{10} \mathrm{CFU} / \mathrm{g}\right)$} \\
\hline & & Day 0 & Day 1 & Day 3 & Day 0 & Day 1 & Day 3 \\
\hline Positive control & & $4.6 \pm 0.8^{\mathrm{a}}$ & $4.8 \pm 0.2^{\mathrm{a}}$ & $4.7 \pm 0.4^{a}$ & - & - & - \\
\hline PBS & & $4.4 \pm 0.1^{\mathrm{a}}$ & $4.2 \pm 0.1^{\mathrm{a}, \mathrm{b}}$ & $4.1 \pm 0.0^{\mathrm{a}, \mathrm{b}}$ & 0.2 & 0.6 & 0.6 \\
\hline Water & & $3.5 \pm 0.4^{\mathrm{a}, \mathrm{b}}$ & $3.5 \pm 0.5^{\mathrm{a}, \mathrm{b}}$ & $4.7 \pm 0.7^{a}$ & 1.1 & 1.3 & 0 \\
\hline $\mathrm{HP}$ & & $2.0 \pm 0.9^{\mathrm{b}, \mathrm{c}}$ & $3.3 \pm 0.9^{\mathrm{b}}$ & $3.5 \pm 0.4^{\mathrm{a}, \mathrm{b}}$ & 2.6 & 1.5 & 1.2 \\
\hline Olive extract & 1 & $3.7 \pm 0.7^{\mathrm{a}, \mathrm{b}}$ & $3.2 \pm 0.7^{\mathrm{b}}$ & $1.4 \pm 0.4^{\mathrm{c}}$ & 0.9 & 1.6 & 3.3 \\
\hline Olive extract & 3 & $2.8 \pm 0.4^{\mathrm{b}, \mathrm{c}}$ & $2.1 \pm 0.0^{\mathrm{b}, \mathrm{c}}$ & $0.8 \pm 0.1^{\mathrm{c}}$ & 1.8 & 2.7 & 3.9 \\
\hline Olive extract & 5 & $1.4 \pm 0.6^{c}$ & $\mathrm{ND}^{\mathrm{d}}$ & $\mathrm{ND}^{\mathrm{c}}$ & 3.2 & 4.8 & 4.7 \\
\hline Apple extract & 1 & $3.5 \pm 0.3^{\mathrm{a}, \mathrm{b}}$ & $3.8 \pm 0.5^{\mathrm{a}, \mathrm{b}}$ & $3.7 \pm 1.3^{\mathrm{a}, \mathrm{b}}$ & 1.1 & 1 & 1 \\
\hline Apple extract & 3 & $3.5 \pm 0.7^{\mathrm{a}, \mathrm{b}}$ & $3.2 \pm 1.0^{\mathrm{a}, \mathrm{b}}$ & $3.5 \pm 1.2^{\mathrm{a}, \mathrm{b}}$ & 1.1 & 1.6 & 1.2 \\
\hline Apple extract & 5 & $3.9 \pm 0.4^{\mathrm{a}, \mathrm{b}}$ & $3.9 \pm 0.5^{\mathrm{a}, \mathrm{b}}$ & $3.3 \pm 1.6^{\mathrm{a}, \mathrm{b}}$ & 0.7 & 0.9 & 1.4 \\
\hline Grape seed extract & 1 & $3.7 \pm 0.7^{\mathrm{a}, \mathrm{b}}$ & $3.7 \pm 0.2^{\mathrm{a}, \mathrm{b}}$ & $3.3 \pm 1.1^{\mathrm{a}, \mathrm{b}}$ & 0.9 & 1.1 & 1.4 \\
\hline Grape seed extract & 3 & $3.9 \pm 0.4^{\mathrm{a}, \mathrm{b}}$ & $3.2 \pm 0.8^{\mathrm{a}, \mathrm{b}}$ & $2.4 \pm 0.2^{\mathrm{b}, \mathrm{c}}$ & 0.7 & 1.6 & 2.3 \\
\hline Grape seed extract & 5 & $3.4 \pm 0.6^{\mathrm{a}, \mathrm{b}}$ & $1.2 \pm 0.1^{\mathrm{c}, \mathrm{d}}$ & $2.2 \pm 0.3^{\mathrm{b}, \mathrm{c}}$ & 1.2 & 3.6 & 2.5 \\
\hline
\end{tabular}

1 PBS: Phosphate Buffered Saline; HP: Hydrogen Peroxide

2 Values represent average mean of three replications. Standard deviation for surviving E. coli O157:H7 population (Log $\left.\mathrm{CFU}_{10} \mathrm{~g}\right)$ is presented following mean value.

3 Mean values with letters a, b, c, etc. provide evidence of significant difference $(\mathrm{P}<0.05)$, where different letters represent statistical significance between treatments for the same sampling day.

$4 \mathrm{ND}=$ No growth detected

5 '-'Indicates control 
Table 2. Antimicrobial effects of olive, apple, and grape seed extracts at 1, 3, and 5\% concentrations against Escherichia coli O157:H7 on mature spinach at $4^{\circ} \mathrm{C}$

\begin{tabular}{|c|c|c|c|c|c|c|c|}
\hline \multirow[b]{2}{*}{ Treatment } & \multirow[b]{2}{*}{ Concentration $(\%)$} & \multicolumn{3}{|c|}{$\begin{array}{c}\text { Surviving E. coli O157:H7 Population } \\
\left(\log _{10} \mathrm{CFU} / \mathrm{g}\right)\end{array}$} & \multicolumn{3}{|c|}{$\begin{array}{l}\text { Log Reductions }\left(\log _{10}\right. \\
\text { CFU/g) }\end{array}$} \\
\hline & & Day 0 & Day 1 & Day 3 & Day 0 & Day 1 & Day 3 \\
\hline Positive control & & $4.6 \pm 0.7^{a}$ & $4.7 \pm 1.0^{\mathrm{a}}$ & $4.8 \pm 0.4^{a}$ & - & - & - \\
\hline PBS & & $3.4 \pm 0.7^{\mathrm{a}, \mathrm{b}}$ & $3.6 \pm 1.0^{\mathrm{a}, \mathrm{b}}$ & $3.3 \pm 0.9^{\mathrm{a}, \mathrm{b}}$ & 1.2 & 1.1 & 1.5 \\
\hline Water & & $3.7 \pm 1.0^{\mathrm{a}, \mathrm{b}}$ & $3.3 \pm 0.8^{\mathrm{a}, \mathrm{b}}$ & $3.3 \pm 0.9^{\mathrm{a}, \mathrm{b}}$ & 0.9 & 1.4 & 1.5 \\
\hline $\mathrm{HP}$ & & $2.9 \pm 0.3^{\mathrm{b}, \mathrm{c}}$ & $2.3 \pm 1.1^{\mathrm{b}, \mathrm{c}}$ & $2.5 \pm 0.7^{\mathrm{b}}$ & 1.7 & 2.4 & 2.3 \\
\hline Olive extract & 1 & $3.0 \pm 0.1^{\mathrm{a}, \mathrm{b}}$ & $2.2 \pm 1.0^{\mathrm{b}, \mathrm{c}}$ & $1.9 \pm 0.5^{b}$ & 1.6 & 2.5 & 2.9 \\
\hline Olive extract & 3 & $2.3 \pm 0.9^{\mathrm{b}, \mathrm{c}}$ & $1.5 \pm 0.4^{\mathrm{c}, \mathrm{d}}$ & $\mathrm{ND}^{\mathrm{c}}$ & 2.3 & 3.2 & 4.8 \\
\hline Olive extract & 5 & $1.6 \pm 0.3^{c}$ & $0.4 \pm 0.1^{\mathrm{d}}$ & $\mathrm{ND}^{\mathrm{c}}$ & 3 & 4.3 & 4.8 \\
\hline Apple extract & 1 & $3.6 \pm 0.9^{\mathrm{a}, \mathrm{b}}$ & $3.5 \pm 1.2^{\mathrm{a}, \mathrm{b}}$ & $3.4 \pm 1.1^{\mathrm{a}, \mathrm{b}}$ & 1 & 1.2 & 1.4 \\
\hline Apple extract & 3 & $3.3 \pm 0.9^{\mathrm{a}, \mathrm{b}}$ & $3.0 \pm 0.9^{\mathrm{a}, \mathrm{b}, \mathrm{c}}$ & $3.2 \pm 0.9^{\mathrm{a}, \mathrm{b}}$ & 1.3 & 1.7 & 1.6 \\
\hline Apple extract & 5 & $3.0 \pm 1.4^{\mathrm{a}, \mathrm{b}}$ & $2.6 \pm 1.5^{\mathrm{b}, \mathrm{c}}$ & $2.6 \pm 0.2^{\mathrm{b}}$ & 1.6 & 2.1 & 2.2 \\
\hline Grape seed extract & 1 & $3.8 \pm 0.6^{\mathrm{a}, \mathrm{b}}$ & $3.8 \pm 0.9^{\mathrm{a}, \mathrm{b}}$ & $2.9 \pm 0.3^{b}$ & 0.8 & 0.9 & 1.9 \\
\hline Grape seed extract & 3 & $3.3 \pm 0.9^{\mathrm{a}, \mathrm{b}}$ & $3.3 \pm 1.0^{\mathrm{a}, \mathrm{b}}$ & $2.2 \pm 0.1^{\mathrm{b}}$ & 1.3 & 1.4 & 2.6 \\
\hline Grape seed extract & 5 & $3.7 \pm 0.7^{\mathrm{a}, \mathrm{b}}$ & $3.3 \pm 0.8^{\mathrm{a}, \mathrm{b}}$ & $2.9 \pm 0.1^{\mathrm{b}}$ & 0.9 & 1.4 & 1.9 \\
\hline
\end{tabular}

1 PBS: Phosphate Buffered Saline; HP: Hydrogen Peroxide

2 Values represent average mean of three replications. Standard deviation for surviving E. coli O157:H7 population (Log $\left.\mathrm{CFU}_{10} \mathrm{~g}\right)$ is presented following mean value.

3 Mean values with letters a, b, c, etc. provide evidence of significant difference $(\mathrm{P}<0.05)$, where different letters represent statistical significance between treatments for the same sampling day.

$4 \mathrm{ND}=$ No growth detected

5 '-' Indicates control

Table 3. Antimicrobial effects of olive, apple, and grape seed extracts at 1, 3, and 5\% concentrations against Escherichia coli O157:H7 on romaine lettuce at $4^{\circ} \mathrm{C}$

\begin{tabular}{|c|c|c|c|c|c|c|c|}
\hline & & \multicolumn{3}{|c|}{$\begin{array}{l}\text { Surviving E. coli O157:H7 Population } \\
\left(\log _{10} \mathrm{CFU} / \mathrm{g}\right)\end{array}$} & \multicolumn{3}{|c|}{ Log Reductions $\left(\log _{10} \mathrm{CFU} / \mathrm{g}\right.$} \\
\hline Treatment & Concentration $(\%)$ & Day 0 & Day 1 & Day 3 & Day 0 & Day 1 & Day 3 \\
\hline Positive control & & $5.2 \pm 1.0^{\mathrm{a}}$ & $5.1 \pm 1.3^{\mathrm{a}}$ & $5.3 \pm 1.1^{\mathrm{a}}$ & - & - & - \\
\hline PBS & & $3.7 \pm 1.1^{\mathrm{a}, \mathrm{b}}$ & $3.9 \pm 0.4^{\mathrm{a}, \mathrm{b}}$ & $3.6 \pm 1.0^{\mathrm{a}, \mathrm{b}}$ & 1.5 & 1.2 & 1.7 \\
\hline Water & & $3.1 \pm 1.0^{\mathrm{a}, \mathrm{b}}$ & $3.6 \pm 1.0^{\mathrm{a}, \mathrm{b}}$ & $3.5 \pm 0.9^{\mathrm{a}, \mathrm{b}}$ & 2.1 & 1.5 & 1.8 \\
\hline HP & & $1.6 \pm 0.6^{\mathrm{b}, \mathrm{c}}$ & $2.0 \pm 0.8^{\mathrm{b}}$ & $2.3 \pm 0.7^{\mathrm{b}, \mathrm{c}}$ & 3.6 & 3.1 & 3 \\
\hline Olive extract & 1 & $2.2 \pm 0.8^{\mathrm{b}}$ & $2.8 \pm 1.3^{\mathrm{b}}$ & $1.3 \pm 0.4^{\mathrm{b}, \mathrm{c}}$ & 3 & 2.3 & 4 \\
\hline Olive extract & 3 & $0.5 \pm 0.1^{\mathrm{c}}$ & $0.8 \pm 0.8^{c}$ & $0.8 \pm 0.3^{\mathrm{b}, \mathrm{c}}$ & 4.7 & 4.3 & 4.5 \\
\hline Olive extract & 5 & $\mathrm{ND}^{\mathrm{c}}$ & $\mathrm{ND}^{\mathrm{c}}$ & $\mathrm{ND}^{\mathrm{c}, \mathrm{d}}$ & 5.2 & 5.1 & 5.3 \\
\hline Apple extract & 1 & $3.4 \pm 0.9^{\mathrm{b}}$ & $3.7 \pm 1.1^{\mathrm{a}, \mathrm{b}}$ & $3.7 \pm 0.9^{\mathrm{a}, \mathrm{b}}$ & 1.8 & 1.4 & 1.6 \\
\hline Apple extract & 3 & $3.0 \pm 0.8^{\mathrm{b}}$ & $3.1 \pm 1.0^{\mathrm{a}, \mathrm{b}}$ & $2.7 \pm 1.3^{\mathrm{b}, \mathrm{c}}$ & 2.2 & 2 & 2.6 \\
\hline Apple extract & 5 & $1.3 \pm 0.3^{\mathrm{b}, \mathrm{c}}$ & $1.2 \pm 1.4^{\mathrm{b}, \mathrm{c}}$ & $1.7 \pm 0.9^{\mathrm{b}, \mathrm{c}}$ & 3.9 & 3.9 & 3.6 \\
\hline Grape seed extract & 1 & $1.9 \pm 0.9^{\mathrm{b}, \mathrm{c}}$ & $3.7 \pm 1.4^{\mathrm{a}, \mathrm{b}}$ & $2.5 \pm 0.6^{\mathrm{b}, \mathrm{c}}$ & 3.3 & 1.4 & 2.8 \\
\hline Grape seed extract & 3 & $1.7 \pm 0.9^{\mathrm{b}, \mathrm{c}}$ & $2.8 \pm 1.0^{\mathrm{b}}$ & $1.0 \pm 0.7^{c}$ & 3.5 & 2.3 & 4.3 \\
\hline Grape seed extract & 5 & $2.2 \pm 0.4^{\mathrm{b}}$ & $2.5 \pm 0.6^{\mathrm{b}}$ & $0.9 \pm 0.6^{c}$ & 3 & 2.6 & 4.4 \\
\hline
\end{tabular}

1 PBS: Phosphate Buffered Saline; HP: Hydrogen Peroxide

2 Values represent average mean of three replications. Standard deviation for surviving E. coli O157:H7 population ( $\left.\mathrm{Log}_{10} \mathrm{CFU} / \mathrm{g}\right)$ is presented following mean value.

3 Mean values with letters a, b, c, etc. provide evidence of significant difference $(\mathrm{P}<0.05)$, where different letters represent statistical significance between treatments for the same sampling day.

$4 \mathrm{ND}=$ No growth detected

5 ' - ' Indicates control 
Table 4. Antimicrobial effects of olive, apple, and grape seed extracts at 1, 3, and 5\% concentrations against Escherichia coli O157:H7 on iceberg lettuce at $4^{\circ} \mathrm{C}$

\begin{tabular}{|c|c|c|c|c|c|c|c|}
\hline \multirow[b]{3}{*}{ Treatment } & \multirow[b]{3}{*}{ Concentration $(\%)$} & \multirow{2}{*}{\multicolumn{3}{|c|}{ Surviving E. coli O157:H7 Population }} & \multirow{2}{*}{\multicolumn{3}{|c|}{$\begin{array}{l}\text { Log Reductions }\left(\log _{10}\right. \\
\text { CFU/g) }\end{array}$}} \\
\hline & & & & & & & \\
\hline & & Day 0 & Day 1 & Day 3 & Day 0 & Day 1 & Day 3 \\
\hline Positive control & & $5.3 \pm 1.7^{\mathrm{a}}$ & $5.1 \pm 1.2^{\mathrm{a}}$ & $5.0 \pm 1.0^{a}$ & - & - & - \\
\hline PBS & & $3.8 \pm 0.4^{\mathrm{b}}$ & $3.6 \pm 1.0^{\mathrm{b}, \mathrm{c}}$ & $3.8 \pm 0.4^{\mathrm{a}, \mathrm{b}}$ & 1.5 & 1.5 & 1.2 \\
\hline Water & & $3.4 \pm 0.3^{b}$ & $3.5 \pm 1.0^{\mathrm{b}, \mathrm{c}}$ & $4.0 \pm 1.0^{\mathrm{a}, \mathrm{b}}$ & 1.9 & 1.6 & 1 \\
\hline $\mathrm{HP}$ & & $1.4 \pm 0.3^{\mathrm{c}, \mathrm{d}}$ & $2.3 \pm 0.4^{c}$ & $1.8 \pm 0.4^{\mathrm{c}, \mathrm{d}}$ & 3.9 & 2.8 & 3.2 \\
\hline Olive extract & 1 & $2.7 \pm 0.7^{b, c}$ & $2.8 \pm 1.3^{b, c}$ & $0.3 \pm 0.5^{\mathrm{e}}$ & 2.6 & 2.3 & 4.7 \\
\hline Olive extract & 3 & $1.5 \pm 0.4^{\mathrm{c}, \mathrm{d}}$ & $\mathrm{ND}^{\mathrm{d}}$ & $\mathrm{ND}^{\mathrm{e}}$ & 3.8 & 5.1 & 5 \\
\hline Olive extract & 5 & $1.2 \pm 0.1^{\mathrm{d}}$ & $\mathrm{ND}^{\mathrm{d}}$ & $\mathrm{ND}^{\mathrm{e}}$ & 4.1 & 5.1 & 5 \\
\hline Apple extract & 1 & $3.7 \pm 0.4^{\mathrm{b}}$ & $3.8 \pm 1.0^{\mathrm{a}, \mathrm{b}}$ & $2.9 \pm 0.5^{\mathrm{b}, \mathrm{c}}$ & 1.6 & 1.3 & 2.1 \\
\hline Apple extract & 3 & $3.3 \pm 0.8^{\mathrm{b}}$ & $3.2 \pm 0.3^{\mathrm{b}, \mathrm{c}}$ & $2.5 \pm 0.4^{\mathrm{b}, \mathrm{c}, \mathrm{d}}$ & 2 & 1.9 & 2.5 \\
\hline Apple extract & 5 & $3.3 \pm 1.0^{\mathrm{b}}$ & $2.9 \pm 0.9^{\mathrm{b}, \mathrm{c}}$ & $1.6 \pm 0.4^{\mathrm{d}, \mathrm{e}}$ & 2 & 2.2 & 3.4 \\
\hline Grape seed extract & 1 & $3.2 \pm 1.0^{\mathrm{b}}$ & $3.7 \pm 0.7^{\mathrm{b}}$ & $3.1 \pm 0.4^{\mathrm{c}}$ & 2.1 & 1.4 & 1.9 \\
\hline Grape seed extract & 3 & $3.0 \pm 1.1^{\mathrm{b}}$ & $3.4 \pm 0.9^{\mathrm{b}, \mathrm{c}}$ & $3.2 \pm 0.6^{c}$ & 2.3 & 1.7 & 1.8 \\
\hline Grape seed extract & 5 & $3.3 \pm 0.7^{b}$ & $2.9 \pm 1.0^{\mathrm{b}, \mathrm{c}}$ & $3.3 \pm 0.6^{c}$ & 2 & 2.2 & 1.7 \\
\hline
\end{tabular}

1 PBS: Phosphate Buffered Saline; HP: Hydrogen Peroxide

2 Values represent average mean of three replications. Standard deviation for surviving E. coli O157:H7 population ( $\left.\mathrm{Log}_{10} \mathrm{CFU} / \mathrm{g}\right)$ is presented following mean value.

3 Mean values with letters a, b, c, etc. provide evidence of significant difference $(\mathrm{P}<0.05)$, where different letters represent statistical significance between treatments for the same sampling day.

$4 \mathrm{ND}=$ No growth detected

5 '-' Indicates control

O157:H7 survivors on baby spinach (Table 1) were the least susceptible to all treatments. The effectiveness of the antimicrobial treatments was also dependent on both, concentration as well as storage time.The $\mathrm{pH}$ of the extracts was found to range from 2.89 to 5.43 (Table 5). However, acidity did not seem to influence the antimicrobial effects of the extract formulations since results show that the $\mathrm{pH}$ of the extracts did not correlate with their antimicrobial effects. Apple extract (most acidic) was the least effective in reducing pathogen populations compared to olive or grape seed extracts (Tables 1-4).

\section{Antimicrobial efficacy of olive, grape Seed, and apple ex- tracts against $E$. Coli $\mathrm{O} 157: \mathrm{H} 7$ on organic leafy greens}

Of all the extracts tested, olive extract (at all concentrations tested) was the most effective, resulting in pathogen reductions between 2.9-5.3 $\log \mathrm{CFUg}^{-1}$ for each leafy green by day 3. In romaine lettuce, the $5 \%$ olive extract reduced the pathogen populations to undetectable levels by day 0 , whereas the $1 \%$ and $3 \%$ olive extract treatments resulted in 4.0 and $4.5 \log \mathrm{CFUg}^{-1}$ reductions by day 0 , respectively (Table 3). For iceberg lettuce, no E. coli O157:H7 was recovered on days 1 and 3 after treatment with $3 \%$ and $5 \%$ olive extract whereas a $4.7 \mathrm{log} \mathrm{CFUg}^{-1}$ reduction was observed by day 3 with the $1 \%$ treatment (Table 4). For mature spinach, treatment with $3 \%$ and $5 \%$ olive extract reduced E. coli $\mathrm{O} 157: \mathrm{H} 7$ populations to undetectable levels by day 3 (Table 2). Baby spinach, in comparison to the other leafy greens, showed lower log $\mathrm{CFUg}^{-1}$ reductions in pathogen populations after treatment with $1 \%$ and $3 \%$ olive extract, resulting in 3.3 and $3.9 \mathrm{log} \mathrm{CFUg}^{-1}$ reductions by day 3 , respectively (Table 1 ). Treatment with $5 \%$ olive extract reduced the E. coli $\mathrm{O} 157: \mathrm{H} 7$ populations to undetectable levels by day 1 on baby spinach. Overall, the $5 \%$ olive extract treatment was the most effective treatment and was statistically significant from all other treatments $(\mathrm{P}<0.05)$.

The trend observed in this study, following treatment of leafy greens with olive extract, is similar to that obtained in previous studies by the authors with $S$. Newport [25], where olive extract showed the highest pathogen reduction in comparison to other plant-derived extracts. In the study by Moore et al. [25], the highest $\log \mathrm{CFUg}^{-1}$ reduction observed for each olive extract concentration on leafy greens by day 3 was between $2-3 \operatorname{logs} \mathrm{CFUg}^{-1}$. In comparison, the present study resulted in higher log $\mathrm{CFUg}^{-1}$ reductions of E. coli O157:H7 (2.9-5.3 log $\left.\mathrm{CFUg}^{-1}\right)$ with olive extract formulations (Tables 1-4). This may suggest that compared to $S$. Newport, E. coli O157:H7 is more susceptible to olive extract. Olive extract is known to contain a variety of polyphenols $[24,32,33]$, which have been found to possess antimicrobial activity over a broad range of microorganisms [20,23,37]. Of the many polyphenols found in olive extract, 4-hydroxytyrosol is the most abundant, making $50-70 \%$ of the total composition, and has the greatest biological effect [36]. Previous in vitro studies have indicated that hydroxytyrosol may have broad range antimicrobial activities against other pathogenic bacteria such as Staphylococcus aureus, Vibrio parabaemolyticus, and S. Typhi [3,12]. The present study also establishes this fact with E. coli $\mathrm{O} 157: \mathrm{H} 7$.

Compared to the positive control, grape seed extract also showed significant reductions in E. coli $\mathrm{O} 157: \mathrm{H} 7$ populations on all the leafy greens. By day 3, a reduction of 4.3 and $4.4 \mathrm{log} \mathrm{CFUg}^{-1}$ in pathogen populations was seen in romaine lettuce (Table 3) and that of 2.6 and $2.2 \log \mathrm{CFUg}^{-1}$ was seen in mature spinach (Table 2 ), after treatment with $3 \%$ and $5 \%$ grape seed extracts, respectively. A $2.5 \log \mathrm{CFUg}^{-1}$ reduction after treatment with $5 \%$ grape seed extract was observed in baby spinach (Table 1), while iceberg lettuce showed approximately $2 \log \mathrm{CFUg}^{-1}$ reductions for all 
Table 5. pH values of olive, apple, and grape seed extracts at 1,3 , and $5 \%$ concentrations in phosphate buffered saline

\begin{tabular}{|l|l|l|}
\hline Extract & Concentration $(\%)$ & $\mathrm{pH}$ \\
\hline Grape seed & 1 & 5.43 \\
\hline Grape seed & 3 & 4.96 \\
\hline Grape seed & 5 & 4.76 \\
\hline Olive & 1 & 3.7 \\
\hline Olive & 3 & 3.61 \\
\hline Olive & 5 & 3.51 \\
\hline Apple & 1 & 3.56 \\
\hline Apple & 3 & 3.04 \\
\hline Apple & 5 & 2.89 \\
\hline
\end{tabular}

grape seed extract concentrations by day 3 (Table 4).

A study that investigated the efficacy of grape seed extract as an antimicrobial treatment demonstrated the ability of this plant extract to significantly reduce populations of Campylobacter spp. [35], one of the common bacterial pathogens associated with foodborne disease. Furthermore, grape seed extract has been shown to be very effective against $S$. aureus [11] and against $S$. Typhimurium on spinach, in conjunction with malic acid and lactic acid in electrostatic sprays, resulting in 2.3 to $3.3 \log$ CFU g ${ }^{-1}$ reductions [14]. Similar studies against E. coli $\mathrm{O} 157: \mathrm{H} 7$ with spinach and iceberg lettuce, using grape seed extract at $2 \%$ and $3 \%$ concentration in electrostatic sprays, yielded a 2.1 and $3.8 \mathrm{log}$ reduction, respectively, by day 14 [13]. In the present study, by day 3 , treatment with $3 \%$ grape seed extract showed reductions of $2.6 \log \mathrm{CFUg}^{-1}$ (mature spinach), $2.3 \log \mathrm{CFUg}^{-1}$ (baby spinach), and $1.8 \log \mathrm{CFUg}^{-1}$ (iceberg lettuce). Additionally, washing the aforementioned leafy greens with higher concentration $(5 \%)$ of grape seed extract formulation resulted in reductions between 1.7 to $3.6 \log \mathrm{CFUg}^{-1}$ from day 0-3 (Tables 1-2, 4). On the other hand, treatment of romaine lettuce with $3 \%$ and $5 \%$ grape seed extract yielded over 4 $\log \mathrm{CFUg}^{-1}$ reductions by day 3 (Table 4). These results indicate that the type of produce may have an effect on antimicrobial efficacy against E. coli O157:H7. The antimicrobial properties of grape seed extract may be attributed to the high concentration of polyphenols found in it $[23,34,43]$. Results from the present study confirm the effectiveness of grape seed extract as an antimicrobial against E. coli O157:H7, and suggest that higher concentrations (3\% and $5 \%$ treatments) are more effective against the pathogen on organic leafy greens.

The three concentrations of apple extract did not differ significantly $(\mathrm{P}<0.05)$ from each other in their effectiveness against $E$. coli $\mathrm{O} 157: \mathrm{H} 7$. By day 3, 1\%, 3\% and 5\% apple extracts showed 1.0, 1.2 and $1.4 \log \mathrm{CFUg}^{-1}$ reductions in baby spinach, respectively (Table 1) and 1.4, 1.6, and $2.2 \log \mathrm{CFUg}^{-1}$ reductions in mature spinach, respectively (Table 2). By the third day of storage, treatment with $3 \%$ apple extract was able to produce a reduction of $2.6 \log \mathrm{CFUg}^{-1}$ and treatment with $5 \%$ apple extract resulted in a reduction of $3.6 \operatorname{log~CFUg}^{-1}$ in romaine lettuce (Table 3). For iceberg lettuce, treatment with $3 \%$ and $5 \%$ apple extracts produced reductions of $2.5 \log \mathrm{CFUg}^{-1}$ and $3.4 \log \mathrm{CFUg}^{-1}$ respectively, by day 3 (Table 4).

Apple-skin extract has been tested against other foodborne pathogens and has been shown to be an effective antimicrobial against Salmonella, S. aureus and L. monocytogenes [11,25]. The present study was also able to establish this fact with E. coli O157:H7. The highest reduction in E. coli O157:H7 population (3.9 log $\mathrm{CFUg}^{-1}$ ) was observed with the $5 \%$ apple extract on romaine lettuce by day 0 . Overall, treatment with apple extract at all concentrations yielded lower reductions than treatment with olive or grape seed extract. A similar study by Moore et al [25] also showed similar trends, where treatment of leafy greens with apple extract resulted in lower reductions in $S$. Newport populations than olive extract (1-2 log $\mathrm{CFUg}^{-1}$ reductions in comparison to 2-3 log $\mathrm{CFUg}^{-1}$ reductions with olive treatment). The present study was able to achieve higher $\log \mathrm{CFUg}^{-1}$ reductions of E. coli O157:H7 with apple extract than those observed with $S$. enterica by Moore et al [25]. These results indicate that, compared to $S$. Newport, E. coli O157:H7 may be more susceptible to apple extract formulations.

Hydrogen peroxide (3\%) was used in this study as an organic fresh produce industry control and its effectiveness as an antimicrobial agent, in comparison to apple, olive, and grape seed extracts, was also studied. The highest reduction seen after treatment with 3\% hydrogen peroxide was $3.9 \log \mathrm{CFUg}^{-1}$ by day 0 , for iceberg lettuce (Table 4). Reductions of 1.7-3.6 log $\mathrm{CFUg}^{-1}$ were observed for the rest of the greens by day 0 (Tables 1-3). Compared to the previous studies with $S$. Newport [25], where the maximum reduction observed after treatment with $3 \%$ hydrogen peroxide was about $1 \log \mathrm{CFUg}^{-1}$ in organic leafy greens, higher reductions were observed in the present study. This suggests that hydrogen peroxide may be more effective against E. coli O157:H7 than $S$. Newport. However, it is noteworthy in the present study that by the third sampling day, two of the four leafy greens (baby spinach and romaine lettuce) showed an increase in surviving pathogen populations after treatment with hydrogen peroxide (Tables 1 and 3). These results suggest that hydrogen peroxide does possess antimicrobial properties, but may not be able to maintain long term antimicrobial effects against E. coli O157:H7 in certain produce types. Based on these results, the use of hydrogen peroxide alone as an antimicrobial wash for organic leafy greens may therefore be inadequate.

All three plant extract formulations demonstrated significant $(\mathrm{P}<0.05)$ reductions in E. coli $\mathrm{O} 157: \mathrm{H} 7$ populations on all four types of organic leafy greens tested. This study demonstrates the potential of extracts derived from olives, grape seeds, and apple skins to inactivate multiple strains of E. coli O157:H7 on organic mature and baby spinach, and romaine and iceberg lettuce. The antimicrobial activity of these extracts was greater than that of hydrogen peroxide and continued to decrease pathogen populations over a three day period. Hence, there is potential for these extracts to be used as natural alternatives to chemical sanitizers for washing organic leafy greens during processing. However, 
further investigation needs to be carried out to determine the effectiveness of these antimicrobial treatments against other foodborne pathogens in organic leafy greens as well as other types of fresh produce. Further studies also call for sensory analysis of the tested leafy greens to determine consumer acceptability.

\section{Acknowledgements}

This research was supported by USDA-NIFA-OREI Grant No. 2010-51300-21760.

\section{References}

[1]. Beuchat LR, Adler BB, Lang MM. (2004) Efficacy of chlorine and a peroxyacetic acid sanitizer in killing Listeria monocytogenes on iceberg and romaine lettuce using simulated commercial processing conditions. J Food Prot 67 (6):1092-1308.

[2]. Beuchat LR, Ryu JH. (1997) Produce handling and processing practices. Emerg Infect Dis 3 (4):459-465.

[3]. Bisignano G, Tomaino A, Cascio RL, Crisafi G, Uccella N, et al. (1999) On the in-vitro antimicrobial activity of oleuropein and hydroxytyrosol. J Pharm Pharmacol 51 (8):971-974.

[4]. Centers for Disease Control and Prevention (CDC). Investigation update: Outbreak of shiga toxin-producing E. coli O104 (STEC O104:H4) infections associated with travels to Germany http://www.cdc.gov/ecoli/2011/ ecoliO104/

[5]. Centers for Disease Control and Prevention (CDC). Multistate outbreak of Salmonella infections linked to organic sprouted chia powder http://www. cdc.gov/salmonella/newport-05-14/

[6]. Centers for Disease Control and Prevention (CDC). Multistate outbreak of hepatitis A virus infections linked to pomegranate seeds from Turkey http:// www.cdc.gov/hepatitis/outbreaks/2013/a1b-03-31/index.html

[7]. Centers for Disease Control and Prevention. Multistate outbreak of shiga toxin-producing Escherichia coli O157:H7 infections linked to organic spinach and spring mix blend http://www.cdc.gov/ecoli/2012/O157H7-11-12/

[8]. Crepet A, Albert I, Dervin C, Carlin F. (2006) Estimation of microbial contamination of food from prevalence and concentration data: Application to Listeria Monocytogenes in fresh vegetables. Appl Environ Micro 73(1):250258.

[9]. Dimitri C, Greene C. (2002) Recent growth patterns in the US organic food market. USDA Agricultural Research Service, Resource Economics Division, Information bulletin. (777).

[10]. Doyle M, Erickson M. (2008) Summer Meeting 2007: The problems with fresh produce: An overview. J Appl Micro 105(2):317-330.

[11]. Friedman M, Henika PR, Levin CE. (2013) Bactericidal activities of healthpromoting, food-derived powders against the foodborne pathogens Escherichia coli, Listeria monocytogenes, Salmonella enterica, and Staphylococcus aureus. J Food Sci 78(2):270-275.

[12]. Friedman M, Rasooly R, Do PM, Henika PR. (2011) The olive compound 4-hydroxytyrosol inactivates Staphylococcus aureus bacteria and staphylococcal enterotoxin A (SEA). J Food Sci 76(8):558-563.

[13]. Ganesh V, Hettiarachchy NS, Griffis CL, Martin EM, Ricke SC. (2012) Electrostatic spraying of food-grade organic and inorganic acids and plant extracts to decontaminate Escherichia coli $\mathrm{O} 157: \mathrm{H} 7$ on spinach and iceberg lettuce. J Food Sci 77(7):391-396.

[14]. Ganesh V, Hettiarachchy NS, Ravichandran M, Johnson MG, Griffis CL, et al. (2010) Electrostatic sprays of food-grade acids and plant extracts are more effective than conventional sprays than decontaminating Salmonella Typhimurium on spinach. J Food Sci 75(9):574-579.

[15]. Heaton J, Jones K. (2008) Microbial contamination of fruit and vegetables and the behavior of enteropathogens in the phyllosphere: A review. J Appl Micr 104(3):613-626.

[16]. Islam M, Morgan J, Doyle MP, Phatak SC, Millner P. et al (2004) Persistence of Salmonellaenterica Serovar Typhimurium on lettuce and parsley and in soils on which they were grown in fields treated with contaminated manure composts or irrigation water. Foodborne Pathog Dis 1(1):27-35

[17]. Jay-Russell MT. (2013) What is the risk from wild animals in food-borne pathogen contamination of plants? CAB Reviews 8:40

[18]. Johnston LM, Jaykus L, Moll D, Martinez MC, Anciso J, et al. (2005) A field study of the microbiological quality of fresh produce. J. Food Prot 68 9:1840-1847

[19]. Kim S, Kang D, Kim K, Ha Y, Hwang J, et al. (2010) Antimicrobial activity of plant extracts against Salmonella Typhimurium, Escherichia coli O157:H7, and Listeria monocytogenes on fresh lettuce. J. Food Sci 76 (1):M41-M46.

[20]. Konaté K, Hilou A, Mavoungou JF, Lepengué AN, Souza A, et al. (2012) Antimicrobial activity of polyphenol-rich fractions from Sida alba L. (Malvaceae) against co-trimoxazol-resistant bacteria strains. Ann Clin Micr Antimicrob 11(5).

[21]. Lang MM, Harris LJ, Beuchat LR. (2004) Survival and recovery of Escherichia coliO157:H7, Salmonella, and Listeria monocytogeneson lettuce and parsley as affected by method of inoculation, time between inoculation and analysis, and treatment with chlorinated water. J Food Prot 67(6):1092-1103.

[22]. Leifert C, Ball K, Volakakis N, Cooper JM. (2008) Control of enteric pathogens in ready-to-eat vegetable crops in organic and 'low input' production systems: a HACCP-based approach. J Appl Micr 105(4):931-950

[23]. Makris DP, Boskou G, Andrikopoulos NK. (2007) Polyphenolic content and in vitro antioxidant characteristics of wine industry and other agri-food solid waste extracts. J Food Comp Anal 20 (2):125-132.

[24]. McDonald S, Prenzler PD, Antolovich M, Robards K. (2001) Phenolic content and antioxidant activity of olive extracts. Food Chem 73(1):73-84.

[25]. Moore KL, Patel J, Jaroni D, Friedman M, Ravishankar S. (2011) Antimicrobial activity of apple, hibiscus, olive, and hydrogen peroxide formulations against Salmonellaenterica on organic leafy greens. J Food Prot 74(10):16761683.

[26]. Mukherjee A, Speh D, Dyck E,Diez-Gonzalez F. (2003) Preharvest evaluation of coliforms, Escherichia coli, Salmonella, and Escherichia coli O157:H7 in organic and conventional produce grown by Minnesota farmers. J Food Prot 67(5):894-900

[27]. Ölmez H, Kretzschmar U. (2009) Potential alternative disinfection methods for organic fresh-cut industry for minimizing water consumption and environmental impact. $L W T$ - Food Science and Technology 42(3):686-693.

[28]. Orue N, García S, Feng P, Heredia N. (2013) Decontamination of Salmonella, Shigella, and Escherichia coli $\mathrm{O} 157: \mathrm{H} 7$ from leafy green vegetables using edible plant extracts. J Food Sci 78(2):M290-M296.

[29]. Park CM, Beuchat LR. (1999) Evaluation of sanitizers for killing Escherichia coli O157:H7, Salmonella and naturally occurring microorganisms on cantaloupe, honeydew melons, and asparagus. Dairy Food Environ Sanit 19: 842-847.

[30]. Plotto A, Narciso JA. (2006) Guidelines and acceptable postharvest practices for organically grown produce. HortScience 41:287-291

[31]. Pollack SL. (2001) Consumer demand for fruit and vegetables: The US example. Changing Structure of Global Food Consumption and Trade 6:49-54.

[32]. Ryan D, Robards K, Prenzler P, Jardine D, Herlt T, et al. (1999) Liquid chromatography with electrospray ionization mass spectrometric detection of phenolic compounds from Olea europaea.J Chromatogr A855(2):529-537.

[33]. Ryan D, Robards K. (1998) Critical review. Phenolic compounds in olives. Analyst 123, 31-44.

[34]. Shi J, Yu J, Pohorly JE, Kakuda Y. (2003) Polyphenolics in grape seeds: Biochemistry and functionality. J Med Food 6(4):291-299.

[35]. Silván JM, Mingo E, Hidalgo M, Pascual-Teresa S, Carrascosa A V et al. (2013) Antibacterial activity of a grape seed extract and its fractions against Campylobacter spp. Food Control 29(1):25-31.

[36]. Soni M, Burdock G, Christian M, Bitler C, Crea R. (2006) Safety assessment of aqueous olive pulp extract as an antioxidant or antimicrobial agent in foods. Food Chem Toxicol 44 (7):903-915.

[37]. Taguri T, Tanaka T, Kouno I. (2004) Antimicrobial activity of 10 different plant polyphenols against bacteria causing foodborne disease. Biological and Pharmaceutical Bulletin 27(12):1965-1969.

[38]. Taormina PJ, Beuchat LR. (1999b) Comparison of Chemical Treatments to Eliminate Enterohemorrhagic Escherichia coli O157:H7 on Alfalfa Seeds. J food Prot 62(4): 318-324.

[39]. Trewavas A. (2001) Urban myths of organic farming. Nature 410:409-410

[40]. Trewavas A. (2004) A critical assessment of organic farming-and-food assertions with particular respect to the UK and the potential environmental benefits of no-till agriculture. Crop Prot 23:757-781

[41]. United States Department of Agriculture National Organic Program http:// www.ams.usda.gov/AMSv1.0/nop

[42]. U.S. Food and Drug Administration. Analysis and evaluation of preventive control measures for the control and reduction/elimination of microbial hazards on fresh and fresh-cut produce. Chapter IV: Outbreaks Tables. http:// www.fda.gov/food/foodscienceresearch/safepracticesforfoodprocesses/ ucm091270.htm

[43]. Xia E, Deng G, Guo Y, Li H. (2010) Biological activities of polyphenols from grapes. Int J Mol Sci 11(2):622-646 